\title{
U.S. Quantitative Easing Policy Effect on TAIEX Futures Market Efficiency
}

\author{
Han Ching Huang ${ }^{1}$, Yong Chern $\mathrm{Su}^{2}$, Wei-Shen $\mathrm{Chen}^{2}$ \\ ${ }^{1}$ Department of finance, Chung Yuan Christian University, Taoyuan, Taiwan \\ ${ }^{2}$ Department of finance, National Taiwan University, Taipei, Taiwan \\ Correspondence: Han Ching Huang, Department of finance, Chung Yuan Christian University, Taoyuan, Taiwan.
}

Received: April 14, 2017

doi:10.11114/aef.v4i4.2494
Accepted: May 5, $2017 \quad$ Available online: June 15, 2017

URL: https://doi.org/10.11114/aef.v4i4.2494

\begin{abstract}
This paper examines the market efficiency of the Taiwan Stock Exchange Capitalization Weighted Stock Index (TAIEX) Futures after the announcement of Quantitative Easing $(\mathrm{QE})$ policy. Order imbalance is used to explore the relationship between return and order imbalance. We find that under the unconditional OLS model, lagged order imbalances almost have no significantly positive predictive power for current return. Nonetheless, on the trading day after the announcement of QE 1 policy, one-minute interval data show that the lagged order imbalance has predictive power for current return. Under the conditional OLS model, the reversed relation between current return and lagged order imbalance is not universal; on the other hand, after the announcement of QE 2 policy, the reversed relation between current return and lagged order imbalance is more common. Moreover, under volatility-GARCH $(1,1)$, one-minute interval data shows significantly positive relation between order imbalance and volatility.
\end{abstract}

Keywords: GARCH, order imbalance, quantitative easing

\section{Introduction}

The issues that monetary policy affect the economy situation have been widely discussed and under the spotlight in the peak of the financial crisis from 2007-2011. The most important and well-known monetary policy in recent decade is the Quantitative Easing (QE) by the Federal Reserve (Fed). In this paper, we explore whether it is efficient in the TAIEX futures market; and further to discover, after the announcement of QE 1 and QE 2, whether the market efficiency of the TAIEX futures market is affected.

We focus on the TAIEX futures market because TAIEX Futures are a very popular financial instrument in Taiwan, and the TAIEX Futures market is a high liquidity market. For equity markets with high liquidity, like the NYSE and NASDAQ, earning an abnormal profit has become difficult by executing trading strategies constructed from the relationship between trading volumes and price trends ( $\mathrm{Su}$, Huang and Lin, 2011). In addition, strong liquidity of NYSE market contributes efficiency to the market, forbidding inside traders gaining abnormal returns (Chordia, Huh, Subrahmanyam, 2008). Therefore, we extend our research to the futures market, and to examine whether the liquidity of the market was influenced after the announcement of QE 1 and QE 2.

Because we concern the impact of the announcement of QE 1 and QE 2 on the market efficiency of TAIEX Futures, we explore whether the market lose liquidity after the announcement. Moreover, we examine whether the informed investors have inside information to know forthcoming QE and how large the scale of the monetary policy would be able to gain an abnormal return.

In addition, since the momentum strategy is widely used among investors in the TAIEX futures market (Cheng, Lin, Li, Lai \& Watkins, 2016), we expect positive relations between lagged order imbalance and current return would be discovered in our research. Furthermore, Yu and Chen (1999) indicate that GARCH $(1,1)$ is more appropriate for stock index futures' change process of price and volume. Thus, we apply GARCH $(1,1)$ to test the relation between order imbalance and return of the TAIEX futures. We suppose that order imbalance has positive explanatory power for volatility and return in the TAIEX futures market.

To reinvigorate the economy, a central bank could conduct monetary policy by either raising or lowering its interest rate, and also by increasing monetary supply, such as open market operations. Nonetheless, when the interest rate was driven 
close to zero, which is the bottom line of nominal interest rate and very common after financial crisis from 2007 to 2012 , the only available monetary policy is to instill liquidity to financial markets; in other words, buying securities or other assets from the financial market is the main spirit of quantitative easing policy. This is also why quantitative easing policy is considered as a last resort to reinvigorate the economy.

The term "Quantitative Easing policy" was first introduced by Bank of Japan in 2001. During that time, Bank of Japan adopted quantitative easing policy with expectation to reinvigorate the economy suffering from IT bubble from 1995-2001. Although quantitative easing policy effects are still debated, this extreme monetary policy was also used by the United States and United Kingdom when the risk-free short-term nominal interest rates are close to zero after the financial crisis from 2007 to 2012.

In order to alleviate market illiquidity after the financial crisis, in the United States, the Federal Reserve (the Fed) expanded its balance sheet dramatically. In November 2008, the Fed announced the first round of quantitative easing, known as QE 1, an asset buyback plan which involved agency debt, Mortgage Backed Securities (MBS) and government bond and aggregated USD 1.75 trillion. In November 2010, after seeing no upturn in the economy, the Fed announced a second round of quantitative easing, or "QE 2", buying Treasury securities till June 2011, which aggregated USD 600 billion. In 2012, third and fourth round of quantitative easing, or "QE3" and "QE4", was also announced in September and December 2012.

Since such extreme monetary policy is impactful to worldwide financial markets, we examine the market efficiency before and after the announcement of quantitative easing policy. Considering the level of scale and impact, we explore the impacts of the announcement of QE 1 and QE 2 on financial markets.

The findings of our paper are as follows. Under the unconditional OLS model, lagged order imbalance has predictive power for current return in one-minute interval data on the trading day after the announcement of QE 1. In addition, under conditional OLS model, the reversed relation between current return and lagged order imbalance is more common; in other words, the result to some extent is consistent with Chordia and Subrahmanyam (2004). Under return-GARCH $(1,1)$ model, positive relations between order imbalance and return are common. On the other hand, one-minute interval data shows significantly positive relation between order imbalance and volatility under volatility-GARCH $(1,1)$ model while five-minute interval data and ten-minute interval data show no significant relation between them.

The paper contributes to the literature as follow. The literature about QE focuses on spillover effect (Fratzscher, Lo Duca \& Straub, 2012; Fratzscher, Lo Duca \& Straub, 2016). Nevertheless, there is no research examining the market efficiency of the TAIEX Futures after the announcement of QE policy. We fill the gap to the literature.

The remainder of this paper is organized as follows. Section 2 reviews the literature. In Section 3, we introduce the data and methodology. In Section 4, we discuss the results and Section 5 provides the conclusion.

\section{Literature Review}

To observe the relationship between asset pricing and the bid ask spread, Amihud and Mendelson (1986) develop a model which assumes that investors with different expected holding period trade assets with different relative spreads. They conclude that market-observed expected return is an increasing and concave function of the spread. Wang (1993) proposes a dynamic asset-pricing model under asymmetric information, indicating that the existence of uninformed investors increases the risk premium and supply shocks can affect the risk premium only under asymmetric information. Moreover, information asymmetry among investors can increase price volatility and negative autocorrelation in return.

Brennan, Jegadeesh, and Swaminathan (1993) examine the relation between the number of investment analysts following a firm and the speed of adjustment of the firm's stock price to new information. They find that returns of firms followed by many analysts tend to lead those of firms that are followed by lesser analysts. In addition, firms followed by many analysts also show a faster response. Yu and Chen (1999) use a modified GARCH model to examine the bilateral relationship between volume, price volatility and maturity of the concerned stock index futures. Furthermore, the study indicates that GARCH $(1,1)$ is more appropriate for stock index futures' change process of price and volume.

Chordia and Subrahmanyam (2004) test the relation between order imbalances and daily returns of individual stocks. They find that contemporaneous imbalances are strongly related to contemporaneous returns, but lagged order imbalances only have weak influences or even negative influences on current stock return because of over weighting of historical order imbalance. Chordia, Roll, and Subrahmanyam (2005) examine the relation between order imbalances and stock returns for different intervals. Positive dependence, within short and long time intervals, is shown among order imbalances. Su. Huang and Lin (2011) study the relation between order imbalance, volatility and stock return of top gainers and find that contemporaneous order imbalance has a significantly positive and lag-one order imbalance has a significantly negative influence on stock return. They also find that order imbalance is a good indicator for price discovery, especially to large firms considered in their sample. 


\section{Data and Methodology}

\subsection{The Data}

\subsubsection{Data Sources}

The objective of our paper is to examine whether the effects of monetary policies on TAIEX futures market's ability is efficient. In particular, given that previous researches have mainly focused on the fundamental process of maintaining market efficiency, especially with trading volume and liquidity, we explore whether this mechanism continues after the announcement of the impactful monetary policy.

Since TAIEX Futures has long been regarded as a very popular financial instrument in Taiwan, we examine if the market has the ability to stay efficient after the announcement of QE 1 and QE 2. Though the market of mini-TAIEX futures has higher trading volume, the market participants in the mini-TAIEX futures are less informative because trading cost in the TAIEX futures market is lesser. Considering TAIEX futures markets is more informative, we choose TAIEX futures as our sample in our paper.

First, we regard 11/25/2008 and 11/03/2010 as announcement day of QE 1 and QE 2, respectively. Then, we collect our data from TAIFEX (Taiwan Futures Exchange) for intraday transaction record from 11/24/2008 to 11/27/2008 and from $11 / 02 / 2010$ to $11 / 05 / 2010$. Moreover, we only use the trading data within market time (8:45AM to 01:45PM) and sort the data by 1 -minute interval, 5 -minute interval and 10 -minute interval.

\subsubsection{Data Processing Method}

Based on Lee and Ready (1991), we identify whether a trade is executed at the bid or at ask. A trade is identified as a bid (ask) trade if the traded price is below (above) the middle of the nearest previous bid and ask quotes. However, due to limited availability of high frequency trading data, we apply the tick rule adopted by Booth et al. (2002), which does not identify whether a trade initiated by the buyer or the seller, but allow us to distinguish whether the trading activity is buyer-initiated and seller-initiated. We separate the trading volume as buyer-initiated or seller-initiated to measure order imbalance. If the trade at the end of the 1-minute interval occurs at a price higher than the close price in the previous 1-minute interval, the corresponding 1-minute trading volume will be classified as a buyer-initiated order imbalance. After we distinguish between buyer-initiated and seller-initiated order imbalance, we conduct a series of tests in the following sections.

\subsubsection{Descriptive Statistics}

Based on the data we collected and sorted, and the tick rule adopted by Booth et al. (2002), the descriptive statistics of our sample are shown in Tables 1 and 2. We can see that, in all QE 1 period, we have an average order imbalance of -2.36, and a median of -68.00 , and a maximum of 2231.00, and a minimum of -1490.00 in 1-minute interval. Specifically, the standard deviation of order imbalance and return within the trading day before announcement of QE 1 and QE 2, are obviously higher than other trading days. It is consistent with Wang (1993), which indicates an information asymmetry among investors can increase price volatility and negative autocorrelation in return. Our result could be an evidence of possible information asymmetry of the event of QE in TAIEX futures market.

Table 1 Descriptive Statistics before and after announcement day of QE 1

Panel A. 1-minute time interval

\begin{tabular}{|c|c|c|c|c|c|c|c|c|}
\hline TAIEX futures & & Mean & Median & Maximum & Minimum & Std Dev. & Skewness & Kurtosis \\
\hline \multirow{2}{*}{$\mathrm{T}-2$} & OI & -8.91 & 77.00 & 1102.00 & -994.00 & 388.80 & 0.06 & -0.63 \\
\hline & Return & $0.00 \%$ & $0.00 \%$ & $0.62 \%$ & $-0.59 \%$ & $0.14 \%$ & $-3.71 \%$ & $185.50 \%$ \\
\hline \multirow{2}{*}{$\mathrm{T}-1$} & OI & -20.89 & -166.00 & 2231.00 & -1490.00 & 493.30 & 0.44 & 1.56 \\
\hline & Return & $0.00 \%$ & $0.00 \%$ & $0.64 \%$ & $-0.84 \%$ & $0.16 \%$ & $-13.62 \%$ & $335.39 \%$ \\
\hline \multirow{2}{*}{$\mathrm{T}+1$} & OI & -2.52 & 70.00 & 1453.00 & -1121.00 & 425.67 & -0.01 & 0.02 \\
\hline & Return & $0.00 \%$ & $0.00 \%$ & $0.59 \%$ & $-0.59 \%$ & $0.14 \%$ & $-20.87 \%$ & $204.56 \%$ \\
\hline \multirow{2}{*}{$\mathrm{T}+2$} & OI & 23.56 & 109.00 & 1864.00 & -997.00 & 413.64 & 0.44 & 0.58 \\
\hline & Return & $0.01 \%$ & $0.00 \%$ & $0.51 \%$ & $-0.38 \%$ & $0.10 \%$ & $30.38 \%$ & $229.23 \%$ \\
\hline \multirow{2}{*}{ All Period } & OI & -2.36 & -68.00 & 2231.00 & -1490.00 & 432.52 & 0.26 & 0.77 \\
\hline & Return & $0.00 \%$ & $0.00 \%$ & $0.64 \%$ & $-0.84 \%$ & $0.14 \%$ & $-11.24 \%$ & $287.39 \%$ \\
\hline
\end{tabular}


Panel B. 5-minute time interval

\begin{tabular}{|c|c|c|c|c|c|c|c|c|}
\hline TAIEX futures & & Mean & Median & Maximum & Minimum & Std Dev. & Skewness & Kurtosis \\
\hline \multirow{2}{*}{$\mathrm{T}-2$} & $\mathrm{OI}$ & -144.23 & -941.00 & 3628.00 & -2833.00 & 1764.60 & 0.29 & -1.32 \\
\hline & Return & $-0.02 \%$ & $-0.05 \%$ & $0.87 \%$ & $-0.78 \%$ & $0.31 \%$ & $36.79 \%$ & $66.47 \%$ \\
\hline \multirow{2}{*}{$\mathrm{T}-1$} & OI & -240.85 & -1198.00 & 6420.00 & -4260.00 & 2262.39 & 0.39 & -0.37 \\
\hline & Return & $-0.02 \%$ & $-0.02 \%$ & $1.41 \%$ & $-1.17 \%$ & $0.40 \%$ & $27.38 \%$ & $298.49 \%$ \\
\hline \multirow{2}{*}{$\mathrm{T}+1$} & $\mathrm{OI}$ & -54.33 & 921.00 & 4091.00 & -4519.00 & 1960.99 & -0.02 & -1.01 \\
\hline & Return & $0.00 \%$ & $0.02 \%$ & $0.73 \%$ & $-1.21 \%$ & $0.33 \%$ & $-73.60 \%$ & $233.99 \%$ \\
\hline \multirow{2}{*}{$\mathrm{T}+2$} & $\mathrm{OI}$ & 146.57 & 841.50 & 4463.00 & -2867.00 & 1893.38 & 0.12 & -1.28 \\
\hline & Return & $0.05 \%$ & $0.02 \%$ & $0.72 \%$ & $-0.47 \%$ & $0.22 \%$ & $81.30 \%$ & $165.07 \%$ \\
\hline \multirow{2}{*}{ All Period } & OI & -72.90 & -849.00 & 6420.00 & -4519.00 & 1971.97 & 0.19 & -0.83 \\
\hline & Return & $0.00 \%$ & $-0.02 \%$ & $1.41 \%$ & $-1.21 \%$ & $0.32 \%$ & $0.00 \%$ & $282.04 \%$ \\
\hline
\end{tabular}

Panel C. 10-minute time interval

\begin{tabular}{|c|c|c|c|c|c|c|c|c|}
\hline TAIEX futures & & Mean & Median & Maximum & Minimum & Std Dev. & Skewness & Kurtosis \\
\hline \multirow{2}{*}{$\mathrm{T}-2$} & OI & 122.86 & -90.50 & 6317.00 & -4551.00 & 3537.62 & 0.10 & -1.72 \\
\hline & Return & $-0.04 \%$ & $0.00 \%$ & $0.82 \%$ & $-0.80 \%$ & $0.43 \%$ & $18.19 \%$ & $-87.27 \%$ \\
\hline \multirow{2}{*}{$\mathrm{T}-1$} & OI & -717.48 & -2650.00 & 7625.00 & -6530.00 & 4377.21 & 0.36 & -1.48 \\
\hline & Return & $-0.03 \%$ & $-0.05 \%$ & $1.72 \%$ & $-1.53 \%$ & $0.60 \%$ & $26.15 \%$ & $241.15 \%$ \\
\hline \multirow{2}{*}{$\mathrm{T}+1$} & OI & -721.68 & -2614.50 & 6388.00 & -7273.00 & 3815.01 & 0.41 & -1.16 \\
\hline & Return & $-0.02 \%$ & $-0.02 \%$ & $0.76 \%$ & $-1.18 \%$ & $0.44 \%$ & $-73.57 \%$ & $118.19 \%$ \\
\hline \multirow{2}{*}{$\mathrm{T}+2$} & OI & 1535.11 & 2859.00 & 5877.00 & -4780.00 & 3414.40 & -0.72 & -1.11 \\
\hline & Return & $0.09 \%$ & $0.07 \%$ & $0.88 \%$ & $-0.56 \%$ & $0.29 \%$ & $64.02 \%$ & $195.41 \%$ \\
\hline \multirow{2}{*}{ All Period } & OI & 48.26 & -247.00 & 7625.00 & -7273.00 & 3860.42 & 0.03 & -1.53 \\
\hline & Return & $0.00 \%$ & $0.00 \%$ & $1.72 \%$ & $-1.53 \%$ & $0.45 \%$ & $-6.09 \%$ & $216.81 \%$ \\
\hline
\end{tabular}

\subsection{Methodology}

\subsubsection{Unconditional Lagged Return-Order Imbalances OLS Model}

We apply a multi-regression model to test the impact of five lagged order imbalance on each stock returns during 2 trading days before and after announcement day. The results present the prediction power of lagged order imbalances indicated by Chorda and Subrahmanya (2004).

$$
\mathrm{R}_{\mathrm{t}}=\alpha_{0}+\alpha_{1} \mathrm{OI}_{\mathrm{t}-1}+\alpha_{2} \mathrm{OI}_{\mathrm{t}-2}+\alpha_{3} \mathrm{OI}_{\mathrm{t}-3}+\alpha_{4} \mathrm{OI}_{\mathrm{t}-4}+\alpha_{5} \mathrm{OI}_{\mathrm{t}-5}+\varepsilon_{\mathrm{t}}
$$

where $R_{t}$ is the return at time interval $t$, and is defined as $\ln (\mathrm{Pt})-\ln (\mathrm{Pt}-1), \mathrm{OI}_{t}$ is the order imbalances at time interval $t$.

If the coefficient $\alpha_{1}$ is significantly positive, the lagged-one order imbalances could be explained to have positively predictive power for the next time interval's return (1-minute, 5-minute, or 10-minute). Based on this relation, we can create an imbalance-based profitable trading strategy.

We also explore, after the announcement of QE 1 and QE 2, whether the predictive powers of order imbalances become stronger after considering the market expectation.

\subsubsection{Conditional Contemporaneous Return-order Imbalances OLS Model}

Moreover, we examine the relation between return and contemporaneous and other four lagged order imbalance in different time interval.

$$
\mathrm{R}_{\mathrm{t}}=\alpha_{0}+\alpha_{1} \mathrm{OI}_{\mathrm{t}}+\alpha_{2} \mathrm{OI}_{\mathrm{t}-1}+\alpha_{3} \mathrm{OI}_{\mathrm{t}-2}+\alpha_{4} \mathrm{OI}_{\mathrm{t}-3}+\alpha_{5} \mathrm{OI}_{\mathrm{t}-4}+\varepsilon_{\mathrm{t}}
$$

where $\mathrm{R}_{\mathrm{t}}$ is the return at time $\mathrm{t}$, and is defined as $\ln (\mathrm{Pt})-\ln (\mathrm{Pt}-1), \mathrm{OI}_{\mathrm{t}}$ is the order imbalance at time $\mathrm{t}$. 
Table 2 Descriptive Statistics before and after announcement of QE 2

Panel A. 1-minute time interval

\begin{tabular}{ccccccccc}
\hline \multicolumn{2}{c}{ TAIEX futures } & Mean & Median & Maximum & Minimum & Std Dev. & Skewness & Kurtosis \\
\hline \multirow{2}{*}{ T-2 } & OI & -5.98 & 0.00 & 1048.00 & -976.00 & 234.15 & -0.33 & 3.67 \\
& Return & $0.00 \%$ & $0.00 \%$ & $0.07 \%$ & $-0.08 \%$ & $0.02 \%$ & $-35.66 \%$ & $115.14 \%$ \\
T-1 & OI & -33.93 & 0.00 & 2023.00 & -3196.00 & 588.48 & -0.31 & 3.97 \\
& Return & $0.00 \%$ & $0.00 \%$ & $0.29 \%$ & $-0.24 \%$ & $0.05 \%$ & $26.56 \%$ & $664.28 \%$ \\
\multirow{2}{*}{$\mathrm{T}+1$} & OI & 34.31 & 0.00 & 2715.00 & -1185.00 & 375.50 & 2.07 & 11.63 \\
& Return & $0.00 \%$ & $0.00 \%$ & $0.13 \%$ & $-0.10 \%$ & $0.03 \%$ & $30.16 \%$ & $130.89 \%$ \\
\multirow{2}{*}{$\mathrm{T}+2$} & OI & -36.06 & 0.00 & 1776.00 & -1609.00 & 333.64 & -0.06 & 5.22 \\
& Return & $0.00 \%$ & $0.00 \%$ & $0.13 \%$ & $-0.08 \%$ & $0.03 \%$ & $55.85 \%$ & $242.29 \%$ \\
\multirow{4}{*}{ All Period } & OI & -10.41 & 0.00 & 2715.00 & -3196.00 & 404.67 & 0.10 & 8.74 \\
& Return & $0.00 \%$ & $0.00 \%$ & $0.29 \%$ & $-0.24 \%$ & $0.03 \%$ & $22.92 \%$ & $790.41 \%$ \\
\hline
\end{tabular}

Panel B. 5-minute time interval

\begin{tabular}{ccccccccc}
\hline \multicolumn{2}{c}{ TAIEX futures } & Mean & Median & Maximum & Minimum & Std Dev. & Skewness & Kurtosis \\
\hline \multirow{2}{*}{ T-2 } & OI & -198.46 & 0.00 & 1459.00 & -2796.00 & 1075.78 & -0.41 & -0.64 \\
& Return & $-0.01 \%$ & $0.00 \%$ & $0.10 \%$ & $-0.10 \%$ & $0.04 \%$ & $6.08 \%$ & $-68.25 \%$ \\
\multirow{2}{*}{$\mathrm{T}-1$} & OI & -201.14 & -863.00 & 5361.00 & -7981.00 & 2688.84 & -0.13 & 0.19 \\
& Return & $-0.02 \%$ & $-0.01 \%$ & $0.28 \%$ & $-0.37 \%$ & $0.12 \%$ & $-44.13 \%$ & $106.96 \%$ \\
\multirow{5}{*}{$\mathrm{T}+1$} & OI & 15.85 & 0.00 & 5744.00 & -2837.00 & 1615.30 & 0.90 & 2.05 \\
& Return & $0.01 \%$ & $0.00 \%$ & $0.26 \%$ & $-0.12 \%$ & $0.07 \%$ & $131.83 \%$ & $423.31 \%$ \\
\multirow{2}{*}{$\mathrm{T}+2$} & OI & -130.70 & 0.00 & 3901.00 & -3678.00 & 1461.45 & -0.01 & 0.15 \\
& Return & $0.00 \%$ & $0.00 \%$ & $0.09 \%$ & $-0.17 \%$ & $0.05 \%$ & $-59.05 \%$ & $190.03 \%$ \\
\multirow{2}{*}{ All Period } & OI & -128.61 & 0.00 & 5744.00 & -7981.00 & 1802.48 & 0.00 & 2.01 \\
& Return & $-0.01 \%$ & $0.00 \%$ & $0.28 \%$ & $-0.37 \%$ & $0.08 \%$ & $-40.63 \%$ & $471.27 \%$ \\
\hline
\end{tabular}

Panel C. 10-minute time interval

\begin{tabular}{ccccccccc}
\hline \multicolumn{2}{c}{ TAIEX futures } & Mean & Median & Maximum & Minimum & Std Dev. & Skewness & Kurtosis \\
\hline \multirow{2}{*}{ T-2 } & OI & -414.17 & -1075.00 & 4232.00 & -3161.00 & 2039.67 & 0.44 & -0.79 \\
& Return & $-0.01 \%$ & $-0.01 \%$ & $0.11 \%$ & $-0.14 \%$ & $0.06 \%$ & $-8.57 \%$ & $-23.55 \%$ \\
\multirow{5}{*}{$\mathrm{T}-1$} & OI & -941.66 & -2132.00 & 9275.00 & -12116.00 & 5213.97 & 0.15 & -0.54 \\
& Return & $-0.04 \%$ & $-0.04 \%$ & $0.36 \%$ & $-0.35 \%$ & $0.18 \%$ & $13.12 \%$ & $-36.40 \%$ \\
\multirow{2}{*}{$\mathrm{T}+1$} & OI & -23.34 & 0.00 & 6343.00 & -4598.00 & 2735.11 & 0.20 & -0.34 \\
& Return & $0.01 \%$ & $0.00 \%$ & $0.31 \%$ & $-0.14 \%$ & $0.10 \%$ & $107.12 \%$ & $221.00 \%$ \\
\multirow{2}{*}{$\mathrm{T}+2$} & OI & -341.97 & 0.00 & 6229.00 & -5309.00 & 2783.82 & 0.14 & -0.13 \\
& Return & $0.00 \%$ & $0.00 \%$ & $0.19 \%$ & $-0.17 \%$ & $0.06 \%$ & $49.38 \%$ & $295.84 \%$ \\
\multirow{2}{*}{ All Period } & OI & -430.28 & -725.50 & 9275.00 & -12116.00 & 3383.79 & 0.00 & 0.87 \\
& Return & $-0.01 \%$ & $-0.01 \%$ & $0.36 \%$ & $-0.35 \%$ & $0.11 \%$ & $-1.81 \%$ & $218.04 \%$ \\
\hline
\end{tabular}

According to Chordia and Subrahmanyam (2004), there is a positive relation between current return and contemporaneous order imbalance. Nonetheless, after we control the contemporaneous order imbalances, the relation between current return and lagged order imbalances becomes negative owing to over-weighting. Moreover, we also explore market makers' behavior in different time intervals.

\subsubsection{Dynamic Return-order Imbalance GARCH $(1,1)$ Model}

Since Yu and Chen (1999) argue that index futures could be better described by GARCH $(1,1)$, we introduce GARCH $(1,1)$ model to catch time-variant property of price series. In this model, we explore the dynamic relation between daily return and order imbalance during 2 trading days before and after the announcement of QE 1 and QE 2 .

$$
\mathrm{R}_{\mathrm{t}}=\mathrm{a}+\beta \mathrm{OI}_{\mathrm{t}}+\varepsilon_{t}, \varepsilon_{\mathrm{t}} \mid \Omega_{\mathrm{t}-1} \sim \mathrm{N}\left(0, \mathrm{~h}_{\mathrm{t}}\right), \mathrm{h}_{\mathrm{t}}=\mathrm{A}+\mathrm{B} \mathrm{h}_{\mathrm{t}-1}+\mathrm{C} \varepsilon_{\mathrm{t}-1}^{2}
$$

where $\mathrm{R}_{t}$ is the return at time interval $t$, and is defined as $\ln (\mathrm{Pt})-\ln (\mathrm{Pt}-1), \mathrm{OI}_{\mathrm{t}}$ denotes the explanatory variable of order 
imbalance, $\varepsilon_{t}$ is the residual value of the stock return at time $t, h_{t}$ is the conditional variance at time $t$, and $\Omega_{t-1}$ is the information set in at time $\mathrm{t}-1$.

We examine whether the order imbalance can predict contemporaneous return significantly by observing the significance of $\beta$.

\subsubsection{Dynamic Volatility-Order Imbalance GARCH $(1,1)$ Model}

We also apply $\operatorname{GARCH}(1,1)$ model to analyze the relationship between order imbalance and price volatility in different periods.

$$
\mathrm{R}_{\mathrm{t}}=\mathrm{a}+\varepsilon_{\mathrm{t}} \quad \varepsilon_{\mathrm{t}} \mid \Omega_{\mathrm{t}} \sim \mathrm{N}\left(0, \mathrm{~h}_{\mathrm{t}}\right) \quad \mathrm{h}_{\mathrm{t}}=\mathrm{A}+\mathrm{B} \mathrm{h}_{\mathrm{t}-1}+\mathrm{C} \varepsilon_{\mathrm{t}-1}^{2}+\gamma \mathrm{OI}_{\mathrm{t}}
$$

where $R_{t}$ is the return at time $t$, and is defined as $\ln (\mathrm{Pt})-\ln (\mathrm{Pt}-1)$, and $\mathrm{OI}_{t}$ denotes the explanatory variable of order imbalance, $\varepsilon_{t}$ is the residual value of the TAIEX futures return at time $t, h_{t}$ is the conditional variance at time $t, \Omega_{t-1}$ is the information set in at time $t, \gamma$ is the coefficient describing the impact of the order imbalance on the volatility of the return.

By detecting significance of $\gamma$, we can infer that whether order imbalance has significantly contribution to price volatility.

\subsubsection{Liquidity Measurement}

To test market liquidity, we adopt Chordia, Huh and Subrahmanyam (2009) liquidity estimation model to assess market's liquidity in two different time intervals, pre-crisis and after crisis period. The liquidity measure $\mathrm{L}$ is negatively related to market liquidity. A larger L implies lower liquidity.

The liquidity measure is:

$$
\mathrm{L}=\left|\frac{\lambda_{i}}{P_{i}}\right|
$$

where $\lambda_{\mathrm{i}}$ is the coefficient of lag one order imbalance in unconditional return-order imbalance OLS model at period $I, \mathrm{P}_{\mathrm{i}}$ is the average market close prices of samples in unconditional return-order imbalance OLS model at period $i$.

\section{Empirical Results}

\subsection{Unconditional Lagged Return-order Imbalances Relation}

We use five lagged order imbalances to examine the unconditional lagged return- order imbalance OLS relation. We explore whether lagged order imbalances have positive predictive power for current returns in the TAIEX futures market. The results are presented in Tables 3 and 4, respectively for QE 1 and QE 2.

In Table 3, the coefficient of lagged-one order imbalance is significantly positive at $10 \%$ significance level, only on the day after the announcement of QE 1. Nonetheless, in 5-minute and 10-minute interval, there are no significant relations.

The above results might be investors' lack of experience in QE policy. Investors would consider order imbalance as a hint on market direction which further triggered strong momentum in the TAIEX futures market. In addition, informed investors, who shared homogenous information and are sure about market direction after the announcement of QE 1, would like to split their trades (Kyle, 1985) to avoid revealing information and price risk. The split of the orders causes autocorrelation between order imbalances (Chordia and Subrahmanyam, 2004). As a result, this makes lagged-one order imbalance significantly positive predictive power for current return on that day.

Table 3 Unconditional Lagged Return-Order Imbalance Relation before and after announcement of QE 1

Panel A. 1-minute time interval

\begin{tabular}{cccccccc}
\hline TAIEX futures & Intercept & OI(t-1) & OI(t-2) & OI(t-3) & OI(t-4) & OI(t-5) \\
\hline \multirow{2}{*}{ T-2 } & Coeff. & $-4.40 \mathrm{E}-05$ & $2.22 \mathrm{E}-08$ & $-3.20 \mathrm{E}-08$ & $-2.10 \mathrm{E}-07$ & $-2.10 \mathrm{E}-07$ & $3.00 \mathrm{E}-07$ \\
& t-value & -0.52 & 0.10 & -0.14 & -0.92 & -0.91 & 1.30 \\
\multirow{2}{*}{$\mathrm{T}-1$} & Coeff. & $-2.40 \mathrm{E}-05$ & $2.62 \mathrm{E}-07$ & $-3.10 \mathrm{E}-07$ & $2.47 \mathrm{E}-07$ & $-1.10 \mathrm{E}-07$ & $1.24 \mathrm{E}-07$ \\
& t-value & -0.26 & 1.33 & -1.56 & 1.24 & -0.58 & 0.63 \\
\multirow{2}{*}{$\mathrm{T}+1$} & Coeff. & $-1.50 \mathrm{E}-05$ & $4.24 \mathrm{E}-07$ & $-3.70 \mathrm{E}-07$ & $9.18 \mathrm{E}-08$ & $-9.60 \mathrm{E}-08$ & $-1.10 \mathrm{E}-07$ \\
& t-value & -0.18 & $2.04 * *$ & $-1.74 *$ & 0.44 & -0.46 & -0.52 \\
& Toeff. & $8.87 \mathrm{E}-05$ & $-1.10 \mathrm{E}-10$ & $-1.30 \mathrm{E}-07$ & $2.69 \mathrm{E}-07$ & $1.37 \mathrm{E}-07$ & $-2.60 \mathrm{E}-08$ \\
& t-value & 1.46 & 0.00 & -0.86 & $1.72 *$ & 0.88 & -0.17 \\
\hline
\end{tabular}


Panel B. 5-minute time interval

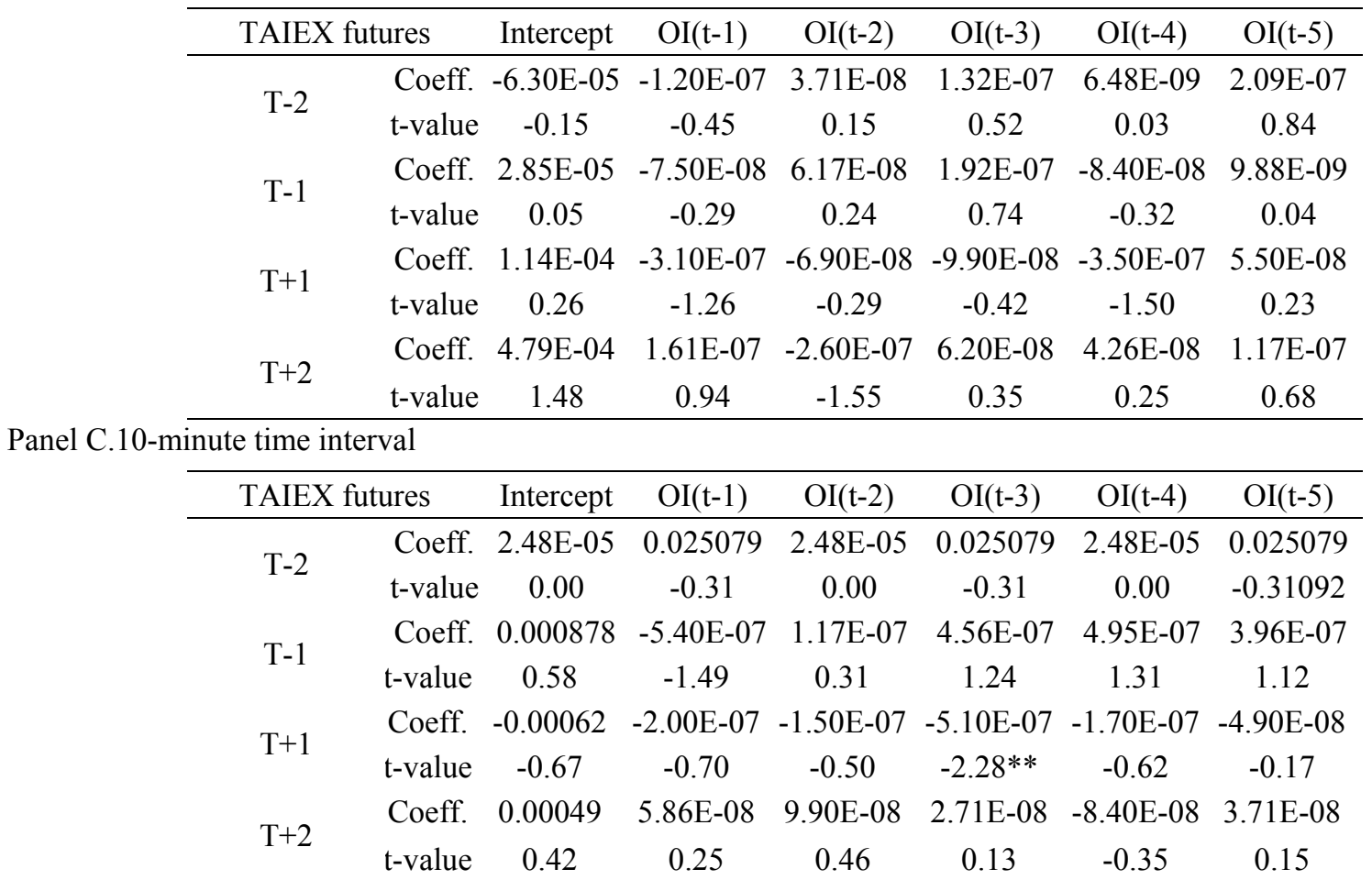

Panel C.10-minute time interval

On the other hand, Table 4 presents that, in QE 2, there is no significantly positive relation with lagged return in every trading day. We conclude that informed investors received heterogeneous information about market direction. Some investors may regard QE 2 as a good policy, while some investors may think of it as a signal of desperate economy. Mixed expectation on the impact of QE 2 makes market movement ambiguous.

Table 4 Empirical Result of unconditional Lagged Return-Order Imbalance Relation before and after announcement of QE 2

Panel A. 1-minute time interval

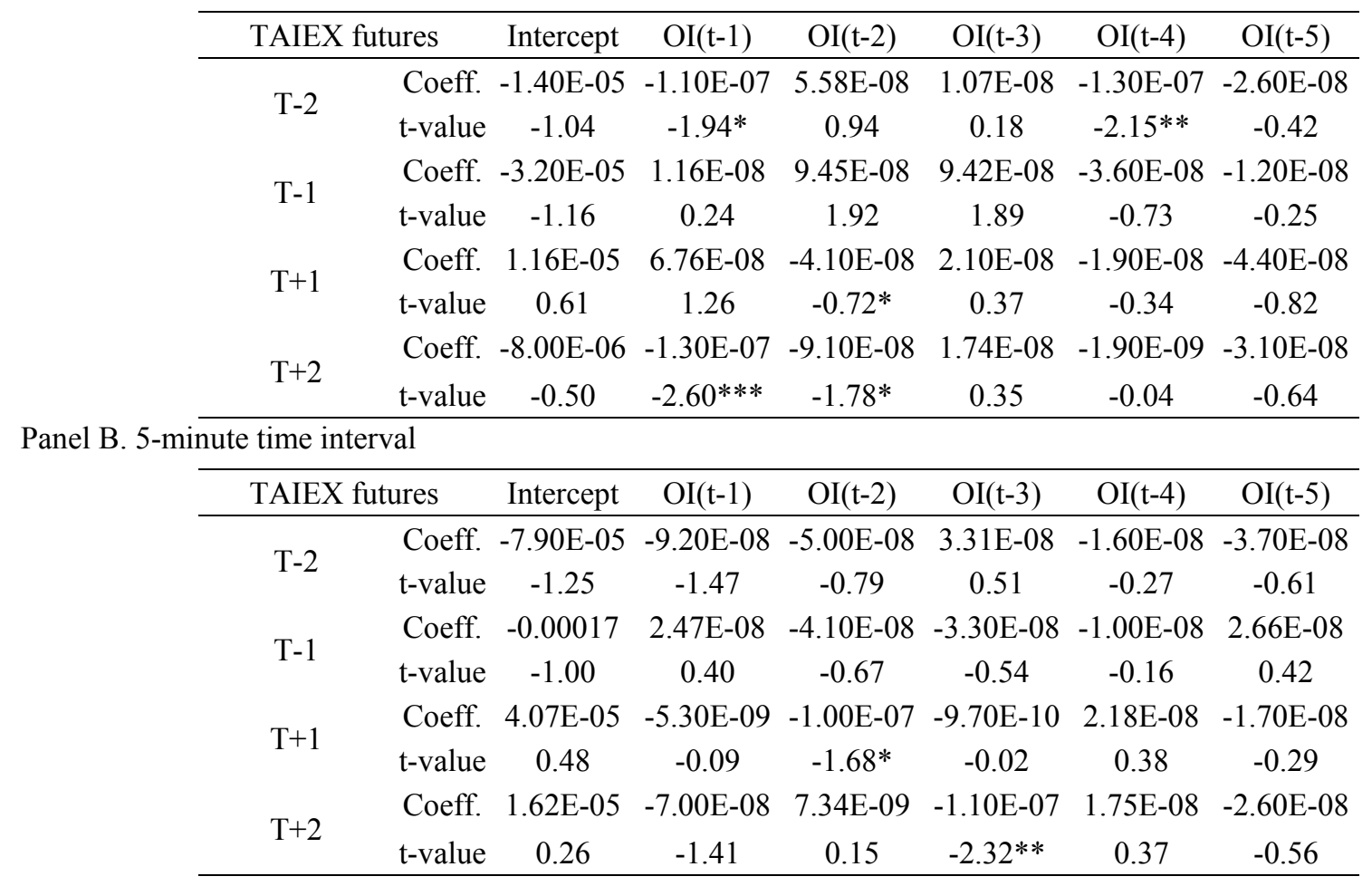


Panel C. 10-minute time interval

\begin{tabular}{cccccccc}
\hline \multirow{2}{*}{ TAIEX futures } & Intercept & $\mathrm{OI}(\mathrm{t}-1)$ & $\mathrm{OI}(\mathrm{t}-2)$ & $\mathrm{OI}(\mathrm{t}-3)$ & $\mathrm{OI}(\mathrm{t}-4)$ & $\mathrm{OI}(\mathrm{t}-5)$ \\
\hline \multirow{2}{*}{$\mathrm{T}-2$} & Coeff. & $-4.00 \mathrm{E}-05$ & $-4.30 \mathrm{E}-08$ & $4.41 \mathrm{E}-08$ & $-6.60 \mathrm{E}-08$ & $1.72 \mathrm{E}-08$ & $1.34 \mathrm{E}-07$ \\
& t-value & -0.28 & -0.58 & 0.55 & -0.88 & 0.24 & $1.98^{*}$ \\
\multirow{2}{*}{$\mathrm{T}-1$} & Coeff. & -0.00062 & $-5.80 \mathrm{E}-08$ & $-7.30 \mathrm{E}-08$ & $-8.30 \mathrm{E}-08$ & $9.26 \mathrm{E}-09$ & $-1.70 \mathrm{E}-07$ \\
& t-value & -1.20 & -0.73 & -0.85 & -0.79 & 0.10 & $-1.98^{*}$ \\
\multirow{2}{*}{$\mathrm{T}+1$} & Coeff. & $4.99 \mathrm{E}-06$ & $-1.40 \mathrm{E}-07$ & $7.70 \mathrm{E}-09$ & $-5.00 \mathrm{E}-08$ & $-1.10 \mathrm{E}-07$ & $-4.40 \mathrm{E}-08$ \\
& t-value & 0.04 & -1.86 & 0.12 & -0.80 & $-1.87^{*}$ & -0.69 \\
\multirow{2}{*}{$\mathrm{T}+2$} & Coeff. & $6.68 \mathrm{E}-05$ & $3.39 \mathrm{E}-09$ & $-6.60 \mathrm{E}-08$ & $5.93 \mathrm{E}-08$ & $4.56 \mathrm{E}-08$ & $-5.60 \mathrm{E}-08$ \\
& t-value & 0.63 & 0.05 & -1.01 & 0.93 & 0.84 & -1.36 \\
\hline
\end{tabular}

We also consider the result as an implication of TAIEX futures market inefficiency. The result of QE 1 means that investors can take advantage of the predictive power of lagged-one order imbalance to earn a positive return. Since the predictive power is significant, we explore if we can also take advantage of the result to develop a trading strategy and beat the market.

\subsection{Conditional Contemporaneous Return-order Imbalances Relation}

We use four lagged order imbalances to examine the conditional lagged return-order imbalance OLS relation. The results are presented in Tables 5 and 6, respectively, for QE 1 and QE 2.

The result shows that the contemporaneous order imbalance is significantly positive at $1 \%$ significance level in every trading day for different time intervals. The predictive power of contemporaneous order imbalance for return is very uniform.

Table 5 Empirical Result of Conditional Lagged Return-Order Imbalance Relation before and after announcement of QE 1

Panel A. 1-minute time interval

\begin{tabular}{cccccccc}
\hline TAIEX futures & Intercept & $\mathrm{OI}(\mathrm{t})$ & $\mathrm{OI}(\mathrm{t}-1)$ & $\mathrm{OI}(\mathrm{t}-2)$ & $\mathrm{OI}(\mathrm{t}-3)$ & $\mathrm{OI}(\mathrm{t}-4)$ \\
\hline \multirow{2}{*}{$\mathrm{T}-2$} & Coeff. & $-1.40 \mathrm{E}-05$ & $3.36 \mathrm{E}-06$ & $-2.10 \mathrm{E}-07$ & $8.23 \mathrm{E}-08$ & $-9.60 \mathrm{E}-08$ & $-2.80 \mathrm{E}-08$ \\
& $\mathrm{t}-$-value & -0.32 & $27.84^{* * *}$ & $-1.73^{*}$ & 0.68 & -0.79 & -0.24 \\
\multirow{2}{*}{$\mathrm{T}-1$} & Coeff. & $3.10 \mathrm{E}-05$ & $2.83 \mathrm{E}-06$ & $-1.30 \mathrm{E}-07$ & $3.20 \mathrm{E}-09$ & $-1.30 \mathrm{E}-07$ & $-9.60 \mathrm{E}-08$ \\
& $\mathrm{t}$-value & 0.64 & $27.26^{* * *}$ & -1.28 & 0.03 & -1.26 & -0.92 \\
\multirow{2}{*}{$\mathrm{T}+1$} & Coeff. & $-9.00 \mathrm{E}-08$ & $2.85 \mathrm{E}-06$ & $9.92 \mathrm{E}-10$ & $-3.60 \mathrm{E}-07$ & $-5.10 \mathrm{E}-08$ & $5.64 \mathrm{E}-09$ \\
& $\mathrm{t}-$-value & 0.00 & $23.51^{* * *}$ & 0.01 & $-2.89 * * *$ & -0.41 & 0.05 \\
\multirow{2}{*}{$\mathrm{T}+2$} & Coeff. & $3.70 \mathrm{E}-05$ & $2.22 \mathrm{E}-06$ & $9.34 \mathrm{E}-08$ & $-1.30 \mathrm{E}-07$ & $4.30 \mathrm{E}-08$ & $1.57 \mathrm{E}-07$ \\
& t-value & 1.13 & $26.76^{* * *}$ & 1.11 & -1.52 & 0.51 & $1.88^{*}$ \\
\hline
\end{tabular}

Panel B. 5-minute time interval

\begin{tabular}{cccccccc}
\hline TAIEX futures & Intercept & OI(t) & OI(t-1) & OI(t-2) & OI(t-3) & OI(t-4) \\
\hline \multirow{2}{*}{ T-2 } & Coeff. & $5.55 \mathrm{E}-05$ & $1.57 \mathrm{E}-06$ & $-3.00 \mathrm{E}-07$ & $8.41 \mathrm{E}-08$ & $2.55 \mathrm{E}-08$ & $-5.40 \mathrm{E}-08$ \\
& t-value & 0.27 & $13.13^{* * *}$ & $-2.51^{* *}$ & 0.72 & 0.22 & -0.47 \\
\multirow{2}{*}{$\mathrm{T}-1$} & Coeff. & 0.000188 & $1.46 \mathrm{E}-06$ & $-6.20 \mathrm{E}-08$ & $1.18 \mathrm{E}-07$ & $8.63 \mathrm{E}-08$ & $-1.50 \mathrm{E}-07$ \\
& t-value & 0.58 & $10.52^{* * *}$ & -0.44 & 0.84 & 0.61 & -1.02 \\
\multirow{2}{*}{$\mathrm{T}+1$} & Coeff. & 0.000104 & $1.46 \mathrm{E}-06$ & $4.35 \mathrm{E}-09$ & $-1.47 \mathrm{E}-07$ & $-2.50 \mathrm{E}-08$ & $-8.00 \mathrm{E}-08$ \\
& t-value & 0.48 & $12.34^{* * *}$ & 0.04 & -1.30 & -0.22 & -0.70 \\
\multirow{2}{*}{$\mathrm{T}+2$} & Coeff. & 0.000298 & $1.00 \mathrm{E}-06$ & $4.81 \mathrm{E}-08$ & $-1.00 \mathrm{E}-07$ & $4.13 \mathrm{E}-08$ & $8.64 \mathrm{E}-08$ \\
& t-value & 1.85 & $11.87^{* * *}$ & 0.57 & -1.19 & 0.48 & 1.00 \\
\hline
\end{tabular}


Panel C. 10-minute time interval

\begin{tabular}{cccccccc}
\hline TAIEX futures & Intercept & OI(t) & OI(t-1) & OI(t-2) & OI(t-3) & OI(t-4) \\
\hline \multirow{2}{*}{ T-2 } & Coeff. & -0.00039 & $1.20 \mathrm{E}-06$ & $3.28 \mathrm{E}-08$ & $-1.30 \mathrm{E}-07$ & $1.54 \mathrm{E}-07$ & $3.02 \mathrm{E}-08$ \\
& t-value & -1.04 & $10.25^{* * *}$ & 0.29 & -1.18 & 1.41 & 0.28 \\
\multirow{2}{*}{$\mathrm{T}-1$} & Coeff. & 0.001202 & $1.10 \mathrm{E}-06$ & $-3.40 \mathrm{E}-08$ & $1.38 \mathrm{E}-07$ & $1.19 \mathrm{E}-07$ & $9.06 \mathrm{E}-08$ \\
& t-value & 1.26 & $5.06^{* * *}$ & -0.14 & 0.57 & 0.48 & 0.40 \\
\multirow{2}{*}{$\mathrm{T}+1$} & Coeff. & 0.000475 & $9.78 \mathrm{E}-07$ & $-1.30 \mathrm{E}-07$ & $-6.80 \mathrm{E}-08$ & $3.17 \mathrm{E}-08$ & $-1.60 \mathrm{E}-07$ \\
& t-value & 0.87 & $5.67 * * *$ & -0.77 & -0.51 & 0.19 & -0.95 \\
\multirow{2}{*}{$\mathrm{T}+2$} & Coeff. & -0.00085 & $8.06 \mathrm{E}-07$ & $1.55 \mathrm{E}-07$ & $2.05 \mathrm{E}-07$ & $-1.70 \mathrm{E}-07$ & $2.11 \mathrm{E}-07$ \\
& t-value & -1.40 & $6.17^{* * *}$ & 1.30 & $1.75^{*}$ & -1.38 & 1.55 \\
\hline
\end{tabular}

In addition, we find that the relation between lagged-one order imbalance and current return in QE 2 is more negative after controlling contemporaneous order imbalance. Although our results are not as strong as Chordia and Subrahmanyam (2004), there is a result of adjustment for over-weighting on historical order imbalance. Because of ambiguous market direction after the announcement of QE 2, the investors' decisions heavily rely on current order imbalance, thus the dependence results in a correction in the coefficient of lagged order imbalance for current return.

Moreover, little correction in the coefficient of lagged order imbalance for current return in QE 1 is due to autocorrelation of order imbalance which is caused by informed investors' split of trades.

Table 6 Conditional Lagged Return-Order Imbalance Relation before and after announcement of QE 2

Panel A. 1-minute time interval

\begin{tabular}{|c|c|c|c|c|c|c|c|}
\hline \multicolumn{2}{|c|}{ TAIEX futures } & Intercept & $\mathrm{OI}(\mathrm{t})$ & $\mathrm{OI}(\mathrm{t}-1)$ & $\mathrm{OI}(\mathrm{t}-2)$ & $\mathrm{OI}(\mathrm{t}-3)$ & $\mathrm{OI}(\mathrm{t}-4)$ \\
\hline \multirow{2}{*}{$\mathrm{T}-2$} & Coeff. & $-6.80 \mathrm{E}-06$ & $7.83 \mathrm{E}-07$ & $-1.40 \mathrm{E}-07$ & $5.04 \mathrm{E}-09$ & $1.29 \mathrm{E}-08$ & $-2.00 \mathrm{E}-08$ \\
\hline & t-value & -0.86 & $22.97 * * *$ & $-4.13 * * *$ & 0.14 & 0.37 & -0.57 \\
\hline \multirow{2}{*}{$\mathrm{T}-1$} & Coeff. & $-1.70 \mathrm{E}-05$ & $6.68 \mathrm{E}-07$ & $-9.70 \mathrm{E}-08$ & $-2.00 \mathrm{E}-08$ & $3.62 \mathrm{E}-08$ & $2.67 \mathrm{E}-08$ \\
\hline & t-value & -1.07 & $23.50 * * *$ & $-3.37 * * *$ & -0.67 & 1.25 & 0.93 \\
\hline \multirow{2}{*}{$\mathrm{T}+1$} & Coeff. & $-3.00 \mathrm{E}-06$ & $7.15 \mathrm{E}-07$ & $-1.50 \mathrm{E}-07$ & $-9.50 \mathrm{E}-08$ & $2.10 \mathrm{E}-08$ & $-2.50 \mathrm{E}-08$ \\
\hline & t-value & -0.27 & $22.64 * * *$ & $-4.41 * * *$ & $-2.81 * * *$ & 0.62 & -0.77 \\
\hline \multirow{2}{*}{$\mathrm{T}+2$} & Coeff. & $1.11 \mathrm{E}-05$ & 7.19E-07 & $-2.70 \mathrm{E}-08$ & $-7.50 \mathrm{E}-08$ & $-1.90 \mathrm{E}-08$ & $1.95 \mathrm{E}-08$ \\
\hline & $\mathrm{t}$-value & 1.33 & $28.05 * * *$ & -1.02 & $-2.83 * * *$ & -0.71 & 0.76 \\
\hline
\end{tabular}

Panel B. 5-minute time interval

\begin{tabular}{cccccccc}
\hline TAIEX futures & Intercept & OI(t) & OI(t-1) & OI(t-2) & OI(t-3) & OI(t-4) \\
\hline \multirow{2}{*}{ T-2 } & Coeff. & $7.34 \mathrm{E}-06$ & $3.40 \mathrm{E}-07$ & $-6.90 \mathrm{E}-08$ & $-3.20 \mathrm{E}-08$ & $-2.00 \mathrm{E}-08$ & $5.17 \mathrm{E}-09$ \\
& t-value & 0.22 & $11.05 * * *$ & $-2.12^{* *}$ & -1.00 & -0.62 & 0.16 \\
\multirow{2}{*}{$\mathrm{T}-1$} & Coeff. & $-8.20 \mathrm{E}-05$ & $3.84 \mathrm{E}-07$ & $-6.10 \mathrm{E}-09$ & $-1.70 \mathrm{E}-08$ & $-6.20 \mathrm{E}-09$ & $-3.20 \mathrm{E}-09$ \\
& $\mathrm{t}$-value & -1.12 & $14.30^{* * *}$ & -0.23 & -0.62 & -0.23 & -0.12 \\
\multirow{2}{*}{$\mathrm{T}+1$} & Coeff. & $3.02 \mathrm{E}-05$ & $3.34 \mathrm{E}-07$ & $-9.20 \mathrm{E}-08$ & $2.99 \mathrm{E}-08$ & $-3.90 \mathrm{E}-08$ & $8.68 \mathrm{E}-08$ \\
& t-value & 0.58 & $8.79 * * *$ & $-2.50 * *$ & 0.79 & -1.09 & $2.49 * *$ \\
\multirow{2}{*}{$\mathrm{T}+2$} & Coeff. & $1.52 \mathrm{E}-05$ & $2.86 \mathrm{E}-07$ & $-5.70 \mathrm{E}-08$ & $2.91 \mathrm{E}-08$ & $-2.70 \mathrm{E}-08$ & $1.72 \mathrm{E}-09$ \\
& t-value & 0.51 & $12.51 * * *$ & $-2.37 * *$ & 1.29 & -1.18 & 0.08 \\
\hline
\end{tabular}

Panel C. 10-minute time interval

\begin{tabular}{|c|c|c|c|c|c|c|c|}
\hline \multicolumn{2}{|c|}{ TAIEX futures } & Intercept & $\mathrm{OI}(\mathrm{t})$ & $\mathrm{OI}(\mathrm{t}-1)$ & $\mathrm{OI}(\mathrm{t}-2)$ & $\mathrm{OI}(\mathrm{t}-3)$ & $\mathrm{OI}(\mathrm{t}-4)$ \\
\hline \multirow{2}{*}{$\mathrm{T}-2$} & Coeff. & $2.70 \mathrm{E}-05$ & $2.60 \mathrm{E}-07$ & $-1.50 \mathrm{E}-08$ & $1.27 \mathrm{E}-09$ & $2.33 \mathrm{E}-08$ & $3.69 \mathrm{E}-08$ \\
\hline & t-value & 0.34 & $6.84 * * *$ & -0.36 & 0.03 & 0.57 & 0.98 \\
\hline \multirow{2}{*}{ T-1 } & Coeff. & 0.000364 & $3.15 \mathrm{E}-07$ & $9.01 \mathrm{E}-08$ & $9.60 \mathrm{E}-08$ & $7.66 \mathrm{E}-08$ & $3.62 \mathrm{E}-08$ \\
\hline & t-value & 1.38 & $7.84 * * *$ & $1.87 * *$ & $1.92 * *$ & 1.52 & 0.76 \\
\hline \multirow{2}{*}{$\mathrm{T}+1$} & Coeff. & $8.72 \mathrm{E}-05$ & $3.28 \mathrm{E}-07$ & $-2.40 \mathrm{E}-08$ & $6.32 \mathrm{E}-09$ & $1.17 \mathrm{E}-08$ & $2.51 \mathrm{E}-08$ \\
\hline & t-value & 1.37 & $10.07 * * *$ & -0.80 & 0.21 & 0.43 & 0.85 \\
\hline \multirow{2}{*}{$\mathrm{T}+2$} & Coeff. & $3.76 \mathrm{E}-05$ & $2.20 \mathrm{E}-07$ & $7.90 \mathrm{E}-08$ & $5.57 \mathrm{E}-08$ & $5.23 \mathrm{E}-08$ & $4.38 \mathrm{E}-08$ \\
\hline & t-value & 0.78 & $8.43^{* * *}$ & $2.64 * *$ & $1.95 * *$ & $2.06 * *$ & $2.33 * *$ \\
\hline
\end{tabular}




\subsection{Dynamic Return-order Imbalance GARCH $(1,1)$ Relation}

After we relax the assumption of the OLS regression model and adopt GARCH $(1,1)$ for the preciseness of analysis, we expect GARCH $(1,1)$ model to catch the time-variant property of price series. The results are presented in Tables 7 and 8, respectively, for QE 1 and QE 2 .

The results here are rather mixed about the relationship between order imbalances and returns, no matter in the trading day before or after the announcement. Some of them are significantly positive, while some of them are positive or negative insignificantly. In addition, we don't find the relation gets stronger or weaker after the announcement of QE policies. However, it shows that, at $1 \%, 5 \%$ or $10 \%$ significant levels, there's no significantly negative coefficient for the relation between order imbalance and return, which is consistent with the results under the OLS model. Moreover, stock index futures' time-variant property proved by Yu and Chen (1999) is mostly well-described with our results.

Table 7 Dynamic Return-Order Imbalance GARCH $(1,1)$ Relation in QE 1

Panel A. 1-minute time interval

\begin{tabular}{ccccccc}
\hline $\begin{array}{c}\text { Trading } \\
\text { Day }\end{array}$ & B & t-value of B & C & B + C & $\beta$ & $\begin{array}{c}\text { t-value of } \\
\beta\end{array}$ \\
\hline $\mathrm{T}-2$ & 0.7513 & 0 & 0.2470 & 0.998 & $-3.00 \mathrm{E}-07$ & -0.001 \\
$\mathrm{~T}-1$ & 0.8803 & $133.650^{* * *}$ & $6.20 \mathrm{E}-02$ & 0.94 & 0.9998 & $23.349^{* * *}$ \\
$\mathrm{~T}+1$ & 0.8803 & 0 & $6.20 \mathrm{E}-02$ & 0.94 & 1 & 0 \\
$\mathrm{~T}+2$ & $1.60 \mathrm{E}-03$ & 0 & $6.20 \mathrm{E}-02$ & 0.0064 & $2.22 \mathrm{E}-06$ & $9.747^{* * *}$ \\
\hline
\end{tabular}

Panel B. 5-minute time interval

\begin{tabular}{ccccccc}
\hline $\begin{array}{c}\text { Trading } \\
\text { Day }\end{array}$ & B & t-value of B & C & B $+\mathrm{C}$ & $\beta$ & $\begin{array}{c}\text { t-value of } \\
\beta\end{array}$ \\
\hline $\mathrm{T}-2$ & 0.8804 & $40.712^{* * *}$ & $6.20 \mathrm{E}-02$ & $9.42 \mathrm{E}-01$ & 0.9998 & $9.575^{* * *}$ \\
$\mathrm{~T}-1$ & 0.8803 & $69.130^{* * *}$ & $6.20 \mathrm{E}-02$ & $9.42 \mathrm{E}-01$ & 0.9995 & $7.019^{* * *}$ \\
$\mathrm{~T}+1$ & 0.8803 & $51.932^{* * *}$ & $6.20 \mathrm{E}-02$ & $9.42 \mathrm{E}-01$ & 0.9999 & $13.481^{* * *}$ \\
$\mathrm{~T}+2$ & 0.7439 & 0 & 0.2257 & $9.70 \mathrm{E}-01$ & $-4.50 \mathrm{E}-06$ & 0 \\
\hline
\end{tabular}

Panel C: 10-minute time interval

\begin{tabular}{ccccccc}
\hline $\begin{array}{c}\text { Trading } \\
\text { Day }\end{array}$ & B & t-value of B & C & B+C & $\beta$ & $\begin{array}{c}\text { t-value of } \\
\beta\end{array}$ \\
\hline $\mathrm{T}-2$ & 0.8803 & $23.513 * * *$ & $6.20 \mathrm{E}-02$ & $9.42 \mathrm{E}-01$ & 0.9999 & $11.585^{* * *}$ \\
$\mathrm{~T}-1$ & 0.8803 & $21.660^{* * *}$ & $6.20 \mathrm{E}-02$ & $9.42 \mathrm{E}-01$ & 1.0000 & $15.087 * * *$ \\
$\mathrm{~T}+1$ & 0.9910 & $3.998^{* * *}$ & $7.30 \mathrm{E}-05$ & $9.91 \mathrm{E}-01$ & $-7.42 \mathrm{E}-05$ & -0.774 \\
$\mathrm{~T}+2$ & 0.8803 & $23.908^{* * *}$ & $6.20 \mathrm{E}-02$ & $9.42 \mathrm{E}-01$ & 0.9999 & $7.362 * * *$ \\
\hline
\end{tabular}

Table 8 Dynamic Return-Order Imbalance GARCH $(1,1)$ Relation in QE 2

Panel A. 1-minute time interval

\begin{tabular}{ccccccc}
\hline $\begin{array}{c}\text { Trading } \\
\text { Day }\end{array}$ & B & t-value of B & C & B $+\mathrm{C}$ & $\beta$ & $\begin{array}{c}\text { t-value of } \\
\beta\end{array}$ \\
\hline $\mathrm{T}-2$ & 0.8803 & $172.323^{* * * *}$ & $6.10 \mathrm{E}-02$ & $9.42 \mathrm{E}-01$ & 0.9999 & $32.551^{* * *}$ \\
$\mathrm{~T}-1$ & 0.9943 & 0 & $2.30 \mathrm{E}-03$ & $9.97 \mathrm{E}-01$ & $3.32 \mathrm{E}-04$ & 0.005 \\
$\mathrm{~T}+1$ & 0.8803 & $286.750^{* * *}$ & $6.20 \mathrm{E}-02$ & $9.42 \mathrm{E}-01$ & 0.9999 & $39.969 * * *$ \\
$\mathrm{~T}+2$ & 0.7938 & $22.824 * * *$ & 0.1930 & $9.87 \mathrm{E}-01$ & $-1.86 \mathrm{E}-10$ & -0.349 \\
\hline
\end{tabular}

Panel B. 5-minute time interval

\begin{tabular}{ccccccc}
\hline $\begin{array}{c}\text { Trading } \\
\text { Day }\end{array}$ & B & t-value of B & C & B+C & $\beta$ & $\begin{array}{c}\text { t-value of } \\
\beta\end{array}$ \\
\hline $\mathrm{T}-2$ & 0.8803 & $37.950^{* * *}$ & $6.20 \mathrm{E}-02$ & $9.42 \mathrm{E}-01$ & 0.9995 & $6.781^{* * *}$ \\
$\mathrm{~T}-1$ & 0.8803 & $58.954 * * *$ & $6.20 \mathrm{E}-02$ & $9.42 \mathrm{E}-01$ & 0.9995 & $6.943^{* * *}$ \\
$\mathrm{~T}+1$ & 0.8803 & $96.414 * * *$ & $6.20 \mathrm{E}-02$ & $9.42 \mathrm{E}-01$ & 1.0000 & $17.809^{* * *}$ \\
$\mathrm{~T}+2$ & 0.8803 & $200.734^{* * *}$ & $6.20 \mathrm{E}-02$ & $9.42 \mathrm{E}-01$ & 0.9995 & $7.220^{* * *}$ \\
\hline
\end{tabular}


Panel C. 10-minute time interval

\begin{tabular}{ccccccc}
\hline $\begin{array}{c}\text { Trading } \\
\text { Day }\end{array}$ & \multirow{2}{*}{$\mathrm{B}$} & $\mathrm{t}$-value of B & $\mathrm{C}$ & $\mathrm{B}+\mathrm{C}$ & $\beta$ & $\begin{array}{c}\text { t-value of } \\
\beta\end{array}$ \\
\hline $\mathrm{T}-2$ & 0.8803 & $26.356^{* * * *}$ & $6.20 \mathrm{E}-02$ & $9.42 \mathrm{E}-01$ & 0.9999 & $13.882^{* * *}$ \\
$\mathrm{~T}-1$ & 0.8803 & $58.954 * * *$ & $6.20 \mathrm{E}-02$ & $9.42 \mathrm{E}-01$ & 0.9995 & $6.943 * * *$ \\
$\mathrm{~T}+1$ & 0.8803 & $28.180^{* * *}$ & $6.20 \mathrm{E}-02$ & $9.42 \mathrm{E}-01$ & 1.0000 & $15.692^{* * *}$ \\
$\mathrm{~T}+2$ & 0.8803 & $93.033 * * *$ & $6.20 \mathrm{E}-02$ & $9.42 \mathrm{E}-01$ & 0.9995 & $4.755^{* * *}$ \\
\hline
\end{tabular}

\subsection{Dynamic Volatility-order Imbalance GARCH $(1,1)$ Relation}

We also examine the relation between price volatility and order imbalance, and expect that there is a positive relation between price volatility and order imbalances. The results are presented in Tables 9 and 10, respectively, for QE 1 and QE 2.

We find that TAIEX futures' time-variant property is well-described, but only, with our result in 1-minute interval. The coefficients of $\gamma$ in 1-minute interval is greatly larger than those in 5-min and 10-min intervals.

The low connection between order imbalances and price volatility in 5-min and 10-min interval data could be explained by investors' speedy reflection on revealed information in the TAIEX futures market. In other words, investors in the TAIEX futures market can quickly adjust the price risk within 1 to 5 minutes, and order imbalance could only possibly volatile the market within a very short period.

The above result suggests that information in the TAIEX futures market reveals quickly, or the liquidity of the market is abundant enough to provide price stability when facing the unexpected market risk.

Table 9 Dynamic Volatility-Order Imbalance GARCH $(1,1)$ Relation in QE 1

Panel A. 1-minute time interval

\begin{tabular}{ccccccc}
\hline Trading Day & B & t-value of B & C & B + C & $\gamma$ & t-value of $\gamma$ \\
\hline T-2 & 0.8803 & $958.120^{* * *}$ & $6.20 \mathrm{E}-02$ & $9.42 \mathrm{E}-01$ & 0.9990 & $5.956^{* * *}$ \\
T-1 & 0.8803 & $466.487^{* * *}$ & $6.20 \mathrm{E}-02$ & $9.42 \mathrm{E}-01$ & 0.9990 & $4.621^{* * *}$ \\
$\mathrm{~T}+1$ & 0.8803 & $82.583^{* * *}$ & $6.20 \mathrm{E}-02$ & $9.42 \mathrm{E}-01$ & 0.9990 & $4.425^{* * *}$ \\
$\mathrm{~T}+2$ & 0.8803 & $157.700^{* * *}$ & $6.20 \mathrm{E}-02$ & $9.42 \mathrm{E}-01$ & 0.9990 & $5.601^{* * *}$ \\
\hline
\end{tabular}

Panel B. 5-minute time interval

\begin{tabular}{ccccccc}
\hline Trading Day & B & t-value of B & C & B+C & $\gamma$ & t-value of $\gamma$ \\
\hline T-2 & $1.40 \mathrm{E}-06$ & 0 & 0 & $1.44 \mathrm{E}-06$ & $-2.19 \mathrm{E}-07$ & -0.002 \\
$\mathrm{~T}-1$ & $1.60 \mathrm{E}-06$ & 0 & 0 & $1.64 \mathrm{E}-06$ & $-1.35 \mathrm{E}-07$ & -0.002 \\
$\mathrm{~T}+1$ & 0 & 0 & 0 & $0.00 \mathrm{E}+00$ & $-3.55 \mathrm{E}-07$ & -0.003 \\
$\mathrm{~T}+2$ & 0 & 0 & 0 & $0.00 \mathrm{E}+00$ & $-4.91 \mathrm{E}-07$ & -0.004
\end{tabular}

Panel C. 10-minute time interval

\begin{tabular}{ccccccc}
\hline Trading Day & B & t-value of B & C & B+C & $\gamma$ & t-value of $\gamma$ \\
\hline T-2 & 0.880326 & 23.513 & $6.20 \mathrm{E}-02$ & $9.42 \mathrm{E}-01$ & $-6.22 \mathrm{E}-07$ & -0.003 \\
$\mathrm{~T}-1$ & 0 & 0 & 0 & $0.00 \mathrm{E}+00$ & $-1.12 \mathrm{E}-07$ & -0.002 \\
$\mathrm{~T}+1$ & $2.10 \mathrm{E}-07$ & 0 & 0 & $2.12 \mathrm{E}-07$ & $-8.36 \mathrm{E}-08$ & -0.002 \\
$\mathrm{~T}+2$ & 0 & 0 & 0 & $0.00 \mathrm{E}+00$ & $-3.19 \mathrm{E}-07$ & -0.005 \\
\hline
\end{tabular}

Table 10 Dynamic Volatility-Order Imbalance GARCH $(1,1)$ Relation in QE 2

Panel A. 1-minute time interval

\begin{tabular}{ccccccc}
\hline Trading Day & B & t-value of B & C & B+C & $\gamma$ & t-value of $\gamma$ \\
\hline T-2 & $6.70 \mathrm{E}-07$ & 0 & 0 & $6.65 \mathrm{E}-07$ & $-2.00 \mathrm{E}-07$ & -0.004 \\
$\mathrm{~T}-1$ & 0.8803 & $167.759^{* * *}$ & $6.20 \mathrm{E}-02$ & $9.42 \mathrm{E}-01$ & 0.9990 & $5.064^{* * *}$ \\
$\mathrm{~T}+1$ & 0.8803 & $264.597^{* * *}$ & $6.20 \mathrm{E}-02$ & $9.42 \mathrm{E}-01$ & 0.9990 & $6.339^{* * *}$ \\
$\mathrm{~T}+2$ & 0.8803 & $120.323^{* * *}$ & $6.20 \mathrm{E}-02$ & $9.42 \mathrm{E}-01$ & 0.9990 & $4.871^{* * *}$ \\
\hline
\end{tabular}

Panel B. 5-minute time interval

\begin{tabular}{ccccccc}
\hline Trading Day & B & t-value of B & C & B + C & $\gamma$ & t-value of $\gamma$ \\
\hline T-2 & $6.70 \mathrm{E}-07$ & 0 & 0 & $6.65 \mathrm{E}-07$ & $-2.00 \mathrm{E}-07$ & -0.004 \\
$\mathrm{~T}-1$ & $3.10 \mathrm{E}-06$ & 0 & 0 & $3.10 \mathrm{E}-06$ & $-2.30 \mathrm{E}-07$ & -0.003 \\
$\mathrm{~T}+1$ & 0.8803 & $10.362^{* * *}$ & $6.20 \mathrm{E}-02$ & $9.42 \mathrm{E}-01$ & 0.9990 & $2.069^{* *}$ \\
$\mathrm{~T}+2$ & $6.20 \mathrm{E}-08$ & 0 & 0 & $6.15 \mathrm{E}-08$ & $-3.00 \mathrm{E}-07$ & -0.004 \\
\hline
\end{tabular}


Panel C. 10-minute time interval

\begin{tabular}{ccccccc}
\hline Trading Day & B & t-value of B & C & B $+C$ & $\gamma$ & t-value of $\gamma$ \\
\hline T-2 & $6.50 \mathrm{E}-07$ & 0 & 0 & $6.45 \mathrm{E}-07$ & $-3.80 \mathrm{E}-08$ & -0.002 \\
T-1 & 0 & 0 & 0 & $0.00 \mathrm{E}+00$ & $-1.60 \mathrm{E}-08$ & 0 \\
$\mathrm{~T}+1$ & 0 & 0 & 0 & $0.00 \mathrm{E}+00$ & $-1.80 \mathrm{E}-07$ & -0.002 \\
$\mathrm{~T}+2$ & $8.70 \mathrm{E}-06$ & 0 & 0 & $8.73 \mathrm{E}-06$ & $-1.00 \mathrm{E}-07$ & -0.002 \\
\hline
\end{tabular}

\subsection{Liquidity Measurement}

We measure the difference of liquidity of the TAIEX Futures market before and after the announcement of QE 1 and QE 2 and use the liquidity measurement proxy described by Chordia, Huh, and Subrahmanya (2007) to compare the liquidity level in 1-, 5- and 10-minute interval.

From Table 11, we find that, on the trading day before the announcement of QE 1, the price-scaled liquidity measure is 6.23E-11 in 1-minute interval, whereas that is $1.00 \mathrm{E}-10$ after the announcement. This result implies that the TAIEX Futures market has less liquidity on the trading day after the announcement of QE 1 in 1-minute interval.

Similar results is shown on the trading day after the announcement of QE 2 in Table 12. The liquidity measure rises from 1.39E-12 to 8.08E-12 after the announcement, and shows that TAIEX Futures market is less liquid even investors have the experience of QE 1.

However, the empirical results of liquidity measure in 5- and 10-minute interval are mixed. We find the results are consistent with our results in volatility-order imbalance GARCH $(1,1)$ relation. The information revealed in the TAIEX futures market would affect market liquidity in 1-minute interval, while the market will provide sufficient liquidity to stabilize the price within 1 to 5 minutes.

Table 11 Liquidity Measurement in QE 1

Panel A. 1-minute time interval

\begin{tabular}{cccc}
\hline Trading Day & $\lambda \mathrm{i}$ & $\mathrm{Pi}$ & $|\lambda \mathrm{i} / \mathrm{Pi}|$ \\
\hline $\mathrm{T}-2$ & $2.22 \mathrm{E}-08$ & 4031.24 & $5.51 \mathrm{E}-12$ \\
$\mathrm{~T}-1$ & $2.62 \mathrm{E}-07$ & 4202.82 & $6.23 \mathrm{E}-11$ \\
$\mathrm{~T}+1$ & $4.24 \mathrm{E}-07$ & 4221.51 & $1.00 \mathrm{E}-10$ \\
$\mathrm{~T}+2$ & $-1.10 \mathrm{E}-10$ & 4396.02 & $2.50 \mathrm{E}-14$ \\
\hline
\end{tabular}

Panel B. 5-minute time interval

\begin{tabular}{cccc}
\hline Trading Day & $\lambda \mathrm{i}$ & $\mathrm{Pi}$ & $|\lambda \mathrm{i} / \mathrm{Pi}|$ \\
\hline $\mathrm{T}-2$ & $-1.20 \mathrm{E}-07$ & 4031.24 & $2.98 \mathrm{E}-11$ \\
$\mathrm{~T}-1$ & $-7.50 \mathrm{E}-08$ & 4202.82 & $1.78 \mathrm{E}-11$ \\
$\mathrm{~T}+1$ & $-3.10 \mathrm{E}-07$ & 4221.51 & $7.34 \mathrm{E}-11$ \\
$\mathrm{~T}+2$ & $1.61 \mathrm{E}-07$ & 4396.02 & $3.66 \mathrm{E}-11$ \\
\hline
\end{tabular}

Panel C. 10-minute time interval

\begin{tabular}{cccc}
\hline Trading Day & $\lambda \mathrm{i}$ & $\mathrm{Pi}$ & $|\lambda \mathrm{i} / \mathrm{Pi}|$ \\
\hline $\mathrm{T}-2$ & 0.025079 & 4031.24 & $6.22 \mathrm{E}-06$ \\
$\mathrm{~T}-1$ & $-5.40 \mathrm{E}-07$ & 4202.82 & $1.28 \mathrm{E}-10$ \\
$\mathrm{~T}+1$ & $-2.00 \mathrm{E}-07$ & 4221.51 & $4.74 \mathrm{E}-11$ \\
$\mathrm{~T}+2$ & $5.86 \mathrm{E}-08$ & 4396.02 & $1.33 \mathrm{E}-11$ \\
\hline
\end{tabular}

Table 12 Liquidity Measurement in QE 2

Panel A. 1-minute time interval

\begin{tabular}{cccc}
\hline Trading Day & $\lambda \mathrm{i}$ & $\mathrm{Pi}$ & $|\lambda \mathrm{i} / \mathrm{Pi}|$ \\
\hline $\mathrm{T}-2$ & $-1.10 \mathrm{E}-07$ & 8381.64 & $1.31 \mathrm{E}-11$ \\
$\mathrm{~T}-1$ & $1.16 \mathrm{E}-08$ & 8355.26 & $1.39 \mathrm{E}-12$ \\
$\mathrm{~T}+1$ & $6.76 \mathrm{E}-08$ & 8366.23 & $8.08 \mathrm{E}-12$ \\
$\mathrm{~T}+2$ & $-1.30 \mathrm{E}-07$ & 8459.79 & $1.54 \mathrm{E}-11$ \\
\hline
\end{tabular}

Panel B. 5-minute time interval

\begin{tabular}{cccc}
\hline Trading Day & $\lambda \mathrm{i}$ & $\mathrm{Pi}$ & $|\lambda \mathrm{i} / \mathrm{Pi}|$ \\
\hline $\mathrm{T}-2$ & $-9.20 \mathrm{E}-08$ & 4031.24 & $2.28 \mathrm{E}-11$ \\
$\mathrm{~T}-1$ & $2.47 \mathrm{E}-08$ & 4202.82 & $5.88 \mathrm{E}-12$ \\
$\mathrm{~T}+1$ & $-5.30 \mathrm{E}-09$ & 4221.51 & $1.26 \mathrm{E}-12$ \\
$\mathrm{~T}+2$ & $-7.00 \mathrm{E}-08$ & 4396.02 & $1.59 \mathrm{E}-11$ \\
\hline
\end{tabular}


Panel C. 10-minute time interval

\begin{tabular}{cccc}
\hline Trading Day & $\lambda \mathrm{i}$ & $\mathrm{Pi}$ & $|\lambda \mathrm{i} / \mathrm{Pi}|$ \\
\hline $\mathrm{T}-2$ & $-4.30 \mathrm{E}-08$ & 4031.24 & $1.07 \mathrm{E}-11$ \\
$\mathrm{~T}-1$ & $-5.80 \mathrm{E}-08$ & 4202.82 & $1.38 \mathrm{E}-11$ \\
$\mathrm{~T}+1$ & $-1.40 \mathrm{E}-07$ & 4221.51 & $3.32 \mathrm{E}-11$ \\
$\mathrm{~T}+2$ & $3.39 \mathrm{E}-09$ & 4396.02 & $7.71 \mathrm{E}-13$ \\
\hline
\end{tabular}

\subsection{Trading Strategy}

Since the contemporaneous order imbalances have significantly positive influence on stock returns, we form a daily trading strategy based on the sign of large order imbalances to explore whether or not a trader based on this order imbalance trading strategy can beat the market. We cannot base our trades on contemporaneous order imbalance; however, lagged-one order imbalance is observable for trading.

We adopt a simple order imbalance-based trading strategy, which is to long futures when top $10 \%$ order imbalances show up, and to short after observing bottom $10 \%$ order imbalance. In addition, we hold the position for one interval. The results are presented in Table 13 and 14, respectively, for QE 1 and QE 2.

Furthermore, to examine whether the order-imbalance based strategy could beat the market, we compare it with TAIEX future's market current return within each interval, which is also described as a market strategy in Table 13 and 14 . We explore how efficient our strategy is and at what level could the strategy beats the market. We perform paired t-test to examine whether our trading strategy return outperforms market strategy. The t-values, reported in Table 15, and there are panel $\mathrm{A}$ and $\mathrm{B}$ for QE 1 and QE 2 .

By performing our strategy, we find a lower standard deviation of return, which implies that the performance of our strategy is more stable, is general in every trading day for all different time intervals. However, we do not observe generally significant better performance than market strategy. It can be easily observed that, even at $10 \%$ significance level, there is no significant evidence to beat the market by executing the trading strategy.

Table 13 Trading Strategy in QE 1

Panel A.1-minute time interval

\begin{tabular}{cccc}
\hline Trading Day & Statistics & OI-based Strategy & Market Strategy \\
\hline \multirow{2}{*}{$\mathrm{T}-2$} & Mean & $1.58 \mathrm{E}-05$ & $-4.03 \mathrm{E}-05$ \\
& Std. Dev. & 0.0006 & 0.0014 \\
$\mathrm{~T}-1$ & Mean & $2.82 \mathrm{E}-05$ & $-2.06 \mathrm{E}-05$ \\
& Std. Dev. & 0.0007 & 0.0016 \\
$\mathrm{~T}+1$ & Mean & $5.79 \mathrm{E}-05$ & $-7.14 \mathrm{E}-06$ \\
& Std. Dev. & 0.0007 & 0.0014 \\
$\mathrm{~T}+2$ & Mean & $1.35 \mathrm{E}-05$ & $8.72 \mathrm{E}-05$ \\
& Std. Dev. & 0.0005 & 0.0010 \\
\hline
\end{tabular}

Panel B. 5-minute time interval

\begin{tabular}{cccc}
\hline Trading Day & Statistics & OI-based Strategy & Market Strategy \\
\hline \multirow{2}{*}{$\mathrm{T}-2$} & Mean & $7.08 \mathrm{E}-05$ & -0.0002 \\
& Std. Dev. & 0.0008 & 0.0031 \\
$\mathrm{~T}-1$ & Mean & $-5.60 \mathrm{E}-05$ & -0.0002 \\
& Std. Dev. & 0.0008 & 0.0040 \\
$\mathrm{~T}+1$ & Mean & 0.0002 & $-4.42 \mathrm{E}-05$ \\
& Std. Dev. & 0.0012 & 0.0033 \\
$\mathrm{~T}+2$ & Mean & $-9.70 \mathrm{E}-05$ & 0.0005 \\
& Std. Dev. & 0.0005 & 0.0022 \\
\hline
\end{tabular}


Panel C. 10-minute time interval

\begin{tabular}{cccc}
\hline Trading Day & Statistics & OI-based Strategy & Market Strategy \\
\hline \multirow{2}{*}{$\mathrm{T}-2$} & Mean & $7.64 \mathrm{E}-05$ & -0.0004 \\
& Std. Dev. & 0.0015 & 0.0043 \\
$\mathrm{~T}-1$ & Mean & -0.0002 & -0.0003 \\
& Std. Dev. & 0.0011 & 0.0060 \\
$\mathrm{~T}+1$ & Mean & $-9.00 \mathrm{E}-05$ & -0.0001 \\
& Std. Dev. & 0.0006 & 0.0044 \\
$\mathrm{~T}+2$ & Mean & 0.0004 & 0.0009 \\
& Std. Dev. & 0.0017 & 0.0029 \\
\hline
\end{tabular}

Table 14 Trading Strategy in QE 2

Panel A. 1-minute time interval

\begin{tabular}{cccc}
\hline Trading Day & Statistics & OI-based Strategy & Market Strategy \\
\hline \multirow{2}{*}{$\mathrm{T}-2$} & Mean & $-1.20 \mathrm{E}-05$ & $-1.16 \mathrm{E}-05$ \\
& Std. Dev. & 0.0001 & 0.0002 \\
$\mathrm{~T}-1$ & Mean & $2.05 \mathrm{E}-05$ & $-3.80 \mathrm{E}-05$ \\
& Std. Dev. & 0.0003 & 0.0005 \\
$\mathrm{~T}+1$ & Mean & $5.60 \mathrm{E}-06$ & $1.24 \mathrm{E}-05$ \\
& Std. Dev. & 0.0002 & 0.0003 \\
$\mathrm{~T}+2$ & Mean & $-1.19 \mathrm{E}-05$ & $-9.47 \mathrm{E}-06$ \\
& Std. Dev. & 0.0002 & 0.0003 \\
\hline
\end{tabular}

Panel B. 5-minute time interval

\begin{tabular}{cccc}
\hline Trading Day & Statistics & OI-based Strategy & Market Strategy \\
\hline \multirow{2}{*}{$\mathrm{T}-2$} & Mean & $-2.43 \mathrm{E}-05$ & $-5.66 \mathrm{E}-05$ \\
& Std. Dev. & 0.0002 & 0.0004 \\
$\mathrm{~T}-1$ & Mean & $-8.14 \mathrm{E}-05$ & -0.0001 \\
& Std. Dev. & 0.0004 & 0.0012 \\
$\mathrm{~T}+1$ & Mean & $-1.84 \mathrm{E}-05$ & $5.48 \mathrm{E}-05$ \\
& Std. Dev. & 0.0004 & 0.0007 \\
& Mean & $5.96 \mathrm{E}-06$ & $-2.60 \mathrm{E}-05$ \\
$\mathrm{~T}+2$ & Std. Dev. & 0.0003 & 0.0005 \\
\hline
\end{tabular}

Panel C.10-minute time interval

\begin{tabular}{cccc}
\hline Trading Day & Statistics & OI-based Strategy & Market Strategy \\
\hline \multirow{2}{*}{$\mathrm{T}-2$} & Mean & $-6.59 \mathrm{E}-05$ & -0.0001 \\
& Std. Dev. & 0.0002 & 0.0006 \\
$\mathrm{~T}-1$ & Mean & -0.0001 & -0.0004 \\
& Std. Dev. & 0.0004 & 0.0018 \\
$\mathrm{~T}+1$ & Mean & $-1.65 \mathrm{E}-05$ & 0.0001 \\
& Std. Dev. & 0.0001 & 0.0010 \\
$\mathrm{~T}+2$ & Mean & $1.23 \mathrm{E}-05$ & $-2.11 \mathrm{E}-05$ \\
& Std. Dev. & $9.29 \mathrm{E}-05$ & 0.0006 \\
\hline
\end{tabular}

Table 15 Hypothesis Test of Trading Strategy

Panel A. Hypothesis Test Result in QE 1

\begin{tabular}{cccccr}
\hline \multicolumn{2}{c}{ 1-minute Interval } & \multicolumn{2}{c}{ 5-minute Interval } & \multicolumn{2}{c}{ 10-minute Interval } \\
\hline Trading Day & $\mathrm{t}$-value & Trading Day & t-value & Trading Day & t-value \\
$\mathrm{T}-2$ & 0.6055 & $\mathrm{~T}-2$ & 0.615921 & $\mathrm{~T}-2$ & 0.6683 \\
$\mathrm{~T}-1$ & 0.5164 & $\mathrm{~T}-1$ & 0.228152 & $\mathrm{~T}-1$ & 0.0815 \\
$\mathrm{~T}+1$ & 0.705 & $\mathrm{~T}+1$ & 0.415355 & $\mathrm{~T}+1$ & 0.0682 \\
$\mathrm{~T}+2$ & -1.2633 & $\mathrm{~T}+2$ & $-1.99623^{* *}$ & $\mathrm{~T}+2$ & -1.1112 \\
\hline
\end{tabular}


Panel B. Hypothesis Test Result in QE 2

\begin{tabular}{cccccc}
\hline \multicolumn{2}{c}{ 1-minute Interval } & \multicolumn{2}{c}{ 5-minute Interval } & \multicolumn{2}{c}{ 10-minute Interval } \\
\hline Trading Day & $\mathrm{t}$-value & Trading Day & t-value & Trading Day & -value \\
T-2 & -0.026 & $\mathrm{~T}-2$ & 0.507 & $\mathrm{~T}-2$ & 0.4374 \\
$\mathrm{~T}-1$ & 1.6354 & $\mathrm{~T}-1$ & 0.6882 & $\mathrm{~T}-1$ & 0.6295 \\
$\mathrm{~T}+1$ & -0.3474 & $\mathrm{~T}+1$ & -0.5909 & $\mathrm{~T}+1$ & -0.7777 \\
$\mathrm{~T}+2$ & -0.1224 & $\mathrm{~T}+2$ & 0.4844 & $\mathrm{~T}+2$ & 0.2793 \\
\hline
\end{tabular}

\section{Conclusion}

In this study, we focus on TAIEX futures market efficiency to examine whether the market is efficient after the announcement of quantitative easing $(\mathrm{QE})$ policy. We introduce order imbalance to examine the relationship between return and order imbalance. Moreover, compared to Lee and Ready's (1991) general approach to identify buyer- or seller-initiated order imbalance, we apply the tick rule adopted by Booth et al. (2002) in our study. We find that the volatilities of order imbalance and return are the highest on the day before the announcement, implying that some market participants may have the information of the announcement of QE.

We also find that lagged order imbalance has significant predictive power, on the day after QE 1, in 1-minute interval, indicating that informed investors have a homogenous expectation on the rising index market, and thus encourage strong momentum in the TAIEX futures market. In addition, informed investors' split of trades also explains the above result. Nevertheless, there is no significantly positive relation in QE 2 . We infer that the announcement of QE 2 which mixed heterogeneous expectations on stock index market results in insignificant coefficient.

Moreover, the reversed relation between current return and lagged order imbalance is not universal in QE 1; on the other hand, after the announcement of QE 2, the reversed relation between current return and lagged order imbalance is more common. Although the result in QE 2 is not significant, it infers that heterogeneous expectations among investors make investors' eager to update their portfolio with the arrival of new information and cause investors' over-weighting on contemporaneous order imbalance.

In return-GARCH $(1,1)$ model, current return can be explained by order imbalance, and volatility-GARCH $(1,1)$ model shows that the explanatory power of order imbalance disappears in 5- and 10-minute interval. This implies speedy price adjustment on information or sufficient liquidity to reduce volatility. The empirical result of liquidity measure is consistent with the result in Volatility-GARCH $(1,1)$. Mixed results in 5- and 10-minute interval implies that the information revealed in the TAIEX futures market would affect market liquidity in 1-minute interval, while the market will provide sufficient liquidity to stabilize the price within 1 to 5 minutes.

We further develop an order imbalance-based trading strategy to take advantage of market inefficiency after the announcement. The results indicate that even after the announcement of the impactful monetary policy, our trading strategy cannot significantly outperform the market, which suggests market efficiency is maintained at a certain level.

\section{References}

Amihud, Y., \& Mendelson, H. (1986). Asset pricing and the bid-ask spread. Journal of Financial Economics, 17, 223-249. https://doi.org/10.1016/0304-405X(86)90065-6

Booth, G. G., Lin, J. C., Martikainen, T., \& Tse, Y. (2002). Trading and pricing in upstairs and down stairs stock markets. Review of Financial Studies, 15, 1111-1135. https://doi.org/10.1093/rfs/15.4.1111

Brennan, M., \& Subrahmanyam, A. (1996). Market microstructure and asset pricing: On the compensation for illiquidity in stock returns. Journal of Financial Economics, 41, 441-464. https://doi.org/10.1016/0304-405X(95)00870-K

Brennan, M., Jegadeesh, N., \& Swaminathan, B. (1993). Investment analysis and the adjustment of stock prices to common information. Review of Financial Studies, 6, 799-824. https://doi.org/10.1093/rfs/6.4.799

Cheng, T. Y., Lin, C. H., Li, H. C., Lai, S. C., \& Watkins, K. A. (2016). Day Trader Behavior and Performance: Evidence from Taiwan Futures Market. Emerging Markets Finance and Trade, 52, 2495-2511. https://doi.org/10.1080/1540496X.2016.1172205

Chordia, T., \& Subrahmanyam, A. (2004). Order imbalance and individual stock returns: Theory and evidence. Journal of Financial Economics, 72(3), 485-518. https://doi.org/10.1016/S0304-405X(03)00175-2

Chordia, T., Huh, S. W., \& Subrahmanyam, A. (2009). Theory-based illiquidity and asset pricing. The Review of Financial Studies, 22(9), 3629-3668. https://doi.org/10.1093/rfs/hhn121

Chordia, T., Roll, R., \& Subrahmanyam, A. (2005). Evidence on the speed of convergence to market efficiency. Journal of Financial Economics, 76(2), 271-292. https://doi.org/10.1016/j.jfineco.2004.06.004 
Fratzscher, M., Lo Duca, M., \& Straub R. (2012). A global monetary tsunami? on the spillovers of US Quantitative Easing. CEPR Discussion Paper 9195, Centre for Economic Policy Research. https://doi.org/10.2139/ssrn.2164261

Fratzscher, M., Lo Duca, M., \& Straub, R. (2016). On the international spillovers of US quantitative easing. The Economic Journal. https://doi.org/10.1111/ecoj.12435

Kyle, A. S. (1985). Continuous auctions and insider trading. Econometrica, 53(6), 1315-1335. https://doi.org/10.2307/1913210

Lee, C. M. C., \& Ready, M. J. (1991). Inferring trade direction from intraday data. Journal of Finance, 46(2), 733-746. https://doi.org/10.1111/j.1540-6261.1991.tb02683.x

Su, Y. C., Huang, H. C., \& Lin, S.F. (2011). Dynamic relations between order imbalance, volatility and return of top gainers. Applied Economics, March, 1-11. https://doi.org/10.1080/00036846.2010.543080

Wang, J. (1993). A model of intertemporal asset prices under asymmetric information. Review of Economic Studies, 60(2), 249-282. https://doi.org/10.2307/2298057

Yu, S. W., \& Chen, Y. C. (1999). The relationship between volume, volatility and maturity in stock index futures. Chinese Management Review, 2, 43-59. https://doi.org/10.1002/fut.21650

\section{Copyrights}

Copyright for this article is retained by the author(s), with first publication rights granted to the journal.

This is an open-access article distributed under the terms and conditions of the Creative Commons Attribution license which permits unrestricted use, distribution, and reproduction in any medium, provided the original work is properly cited. 